\title{
Polymorphisms in the Cell Wall-Spanning Domain of the C Protein $\beta$-Antigen in Clinical Streptococcus agalactiae Isolates Are Caused by Genetic Instability of Repeating DNA Sequences
}

\author{
REINHARD BERNER, MICHAEL RUESS, STEFAN BERESWILL, AND MATTHIAS BRANDIS \\ University Children's Hospital, D-79106 Freiburg [R.B., M.R., M.B.]; and Institute of Medical \\ Microbiology and Hygiene, Department of Microbiology [S.B.], D-79104 Freiburg, Germany
}

\begin{abstract}
The $\mathrm{C}$ protein $\alpha$ - and $\beta$-antigens are immunodominant components of the surface of Streptococcus agalactiae, the most frequent cause of neonatal sepsis. Both proteins are thought to contribute significantly to virulence of $S$. agalactiae. They are mainly expressed by serotypes $\mathrm{Ia}, \mathrm{Ib}$, and II. The $\mathrm{C}$ protein $\beta$-antigen (C $\beta$-protein) binds to the $\mathrm{Fc}$ portion of human IgA and seems to be of importance in bacterial resistance to mucosal immune defense mechanisms. In this study, PCR analysis of $S$. agalactiae isolates obtained from 189 neonates and 112 pregnant women revealed the presence of the $\mathrm{C} \beta$-protein gene in $19 \%$ and $22 \%$ of the isolates, respectively. Size polymorphisms of the PCR products within the gene region encoding the cell wallspanning domain indicated a high degree of genetic variability. Thirteen different variants of the amplified region were differentiated among the $60 \mathrm{C} \beta$-protein-positive isolates by sequence analysis. In all variants, the polymorphisms were caused by
\end{abstract}

\section{ABSTRACT}

insertions and deletions of repetitive DNA elements that did not alter the open reading frame. Comparison of the $\mathrm{C} \beta$-protein gene polymorphisms showed a significantly higher rate of isolates carrying deletions $>50 \mathrm{bp}$ in serotype $\mathrm{Ib}$ than in serotype II isolates $(p=0.001)$; this was also true for neonatal isolates analyzed separately $(p=0.01)$. Neonatal isolates carried a higher rate of large deletions when compared with maternal isolates; this difference, however, did not reach statistical significance ( $p$ $=0.08$ ). We hypothesize that polymorphisms in the cell wallspanning domain of the $\mathrm{C} \beta$-protein are of functional relevance with regard to maternofetal transmission of the pathogen.

(Pediatr Res 51: 106-111, 2002)
Abbreviations
$\mathbf{C} \boldsymbol{\beta}$-protein, $\mathrm{C}$ protein $\beta$-antigen
GBS, group B streptococci, Streptococcus agalactiae

Bacterial sepsis is still a leading cause of neonatal morbidity and mortality. Recent data from the United States describe an incidence of 3.5 cases per 1000 live births, with a mortality reaching up to $16 \%(1,2)$. Streptococcus agalactiae (GBS) in particular accounts for approximately 1.4 cases of sepsis per 1000 births, and is by far the leading causative agent of neonatal early onset sepsis (2-8). In contrast to the typespecific capsular polysaccharides which are well-defined virulence determinants of GBS (9-12), the role of proteins as factors contributing to pathogenicity is not yet clearly determined. The $\mathrm{C}$ proteins are surface-associated immunodominant antigens expressed by most clinical GBS isolates of capsular types Ia, Ib, and II, but are uncommon in serotype III (13-19). The two different $C$ protein antigens $\alpha$ and $\beta$ are encoded by separate genes, which are independently expressed. Both genes

Received November 29, 2000; accepted August 16, 2001.

Correspondence and reprint requests: Reinhard Berner, M.D., University Children's Hospital, Mathildenstrasse 1, D-79106 Freiburg, Germany; e-mail: berner@kikli.ukl.uni-freiburg.de

Supported by grants of the Deutsche Forschungsgemeinschaft (Be 1756/2-2). have been cloned and analyzed at the molecular level (20-22). In addition, another two $\mathrm{C}$ protein antigens, the $\gamma$ and $\delta$ antigens, were identified (23). Lancefield et al. (24) reported in 1975 that antibodies directed against the $\mathrm{C}$ proteins protect mice against a lethal challenge with $\mathrm{C}$ protein carrying GBS, indicating that these determinants are involved in both virulence and protective immunity. Further studies revealed that the $\mathrm{C}$ proteins contribute to the resistance of opsonization and intracellular killing $(25,26)$. The $\mathrm{C} \beta$-protein binds to the $\mathrm{Fc}$ portion of human $\operatorname{IgA}(27,28)$, which might be of importance in bacterial resistance to mucosal immune defense mechanisms. By binding IgA to the bacterial surface, GBS may block binding of other opsonizing antibodies, mask other antigens on the cell surface, and inhibit phagocytosis (29-31).

The nucleotide sequences of the $\mathrm{C}$ protein $\alpha$ - and $\beta$-antigen genes were determined several years ago (20-22). The structure of the $\alpha$-antigen is characterized by an $\mathrm{N}$-terminal region that is followed by a series of nine tandem repeating units that make up $74 \%$ of the mature protein. Each repeating unit is identical and consists of 82 amino acids, which are encoded by 
246 nucleotides (22). The large region consisting of identical repeating units is thought to define protective epitopes. This structure of the protein and its encoding gene may have a role in generating genotypic and phenotypic variability by providing sites for gene rearrangements that create an antigenic diversity of the $\alpha$-antigen $(22,32,33)$. Concerning a similar repeat unit structure of the $\mathrm{C} \beta$-protein, different and contradictory results have been obtained. Whereas Madoff et al. (32) found little variation among the strains analyzed in their study, Brady and Boyle (16) reported heterogeneity of the $C \beta$-protein size in clinical isolates. Likewise, Maeland et al. (34) demonstrated remarkable variations among the $C \beta$-protein gene and the gene products among different GBS strains, whereas Mawn et al. (33) did not observe varying sizes of PCR products of the $\mathrm{C} \beta$-protein gene. However, in contrast to Maeland et al. (34) who amplified a region of the gene including a part encoding for each of the IgA-binding domains A and B (nucleotides 1337-1940), Mawn et al. (33) analyzed a region downstream, ranging from the nucleotides 2679 to 3270 . We have recently described a remarkable heterogeneity in the $\mathrm{C} \beta$-protein (13) when analyzing clinical isolates with the primers indicated by Mawn et al. (33), but all isolates showed identical sizes of the PCR product when the DNA was amplified according to the primers given by Maeland et al. (34). The region of the gene amplified by Mawn et al. (33) is supposed to belong to a cell wall-spanning domain that has no function in IgA binding. Interestingly, Jerlström et al. (21) as well as Hedden et al. (20) described an unusual feature of this region as containing proline-rich repeated sequences with a three-residue periodicity. The purpose of the present study was to study the previously described genetic diversity within the cell wall-spanning domain of the $C \beta$-protein gene in more detail and to investigate whether individual genotypes are associated with GBS different serotypes and isolates from either neonatal or maternal origin.

\section{METHODS}

Bacterial strains. GBS strains were collected from clinical specimens at the University Children's Hospital, Freiburg, Germany, from 1991 through 1999, and included those recently described (13). Bacteria were isolated from blood, meconium, urine, and superficial swab cultures from newborns admitted to the University Children's Hospital, for clinical suspicion of sepsis or for routine screening. GBS isolates from vaginal swabs of pregnant women were randomly collected, 50 of them in 1997, 62 of them in 1999. GBS isolates were identified by characteristic growth on blood agar plates, by $\beta$-hemolysis, and by serology grouping, using the latex agglutination test (Streptex, Murex Diagnostics, Dartford, U.K.).

DNA preparation. DNA was isolated as previously described (13). For PCR experiments, precipitated chromosomal DNA was pelleted and adjusted spectrophotometrically to a concentration of $10 \mathrm{ng} / \mu \mathrm{L}$ with $\mathrm{H}_{2} \mathrm{O}$.

PCR assay. PCR assays were performed as described in detail previously (13). The isolated bacterial DNA was used as a target. Oligonucleotide primers specific for amplification of the IgA-binding domain of the $\mathrm{C} \beta$-protein gene were used as proposed by Maeland et al. (34) corresponding to the nucleotides 1337-1360 (5'-AAG GCT ATG AGT GAG AGC TTG GAG-3') and 1917-1940 (5'-CTG CTC TGG TGT TTT AGG AAC TTG-3') of the $C \beta$-protein gene sequence (21). These primers amplify a DNA fragment of $604 \mathrm{bp}$ that encodes for a part of each of the IgA-binding domains A and B of the $\mathrm{C} \beta$-protein gene. For amplification of a DNA fragment corresponding to the region from nucleotide position 2725 to 3287 , primers located within the region of the membrane- and cell wall-spanning domain of the $\mathrm{C} \beta$-protein were designed from published sequence data [(21), GeneBank accession number X59771]. PCR assay was performed with the antisense primer 5'-TTA TCA GCC AAC TCT TTC GTC-3' and the sense primer 5'-CTT AGT ACA CGA TGC ATT CTC-3'. Within this region we had previously observed genetic polymorphisms (13).

DNA sequencing. To determine the nucleotide sequence of amplified DNA, PCR products were purified using the QIAquick PCR Purification Kit (QIAGEN GmbH, Hilden, Germany) and subjected to DNA sequence analysis using the AmpliTaq DNA Polymerase DNA Sequencing Kit (Dye Terminator, Cycle Sequencing Ready Reaction; PerkinElmer Life Science, Boston, MA, U.S.A.). Products from sequencing reactions were analyzed with a sequence apparatus (model 370A, Applied Biosystems, Foster City, CA, U.S.A.).

Serotyping. Serotyping of GBS isolates was performed as described previously (13), using an enzymatic extraction method. Typing was performed with antisera specific for capsular serotypes Ia, Ib, II, III, IV, and V in a slide agglutination test (Denka Seiken, Tokyo, Japan).

Statistical analysis. Fisher's exact test was applied for analysis of prevalence of individual GBS genotypes and DNA polymorphisms among maternal and neonatal isolate populations and for the associations with certain serotypes. Analyses were performed using the SPSS-software package, version 10.0 (SPSS, Chicago, IL, U.S.A.). $P$ values $<0.05$ were considered significant.

\section{RESULTS}

Detection of C $\boldsymbol{C}$-protein gene in isolates of maternal and neonatal origin. One hundred eighty-nine GBS isolates from newborns and 112 GBS isolates of maternal origin were analyzed by the PCR method for the presence of the $\mathrm{C} \beta$-protein gene. The $\mathrm{C} \beta$-protein gene was detected in 35 neonatal isolates $(19 \%)$ and 25 maternal isolates $(22 \%)$. Clinical characteristics of neonatal strains harboring the $C \beta$-protein gene are shown in Table 1. The $\mathrm{C} \beta$-protein gene-positive isolates were subjected to serotyping, which revealed that the majority of the neonatal isolates belonged to serotype $\mathrm{Ib}$ ( 18 isolates, $51 \%$ ), followed by serotype II (11 isolates, 31\%). Among maternal isolates, nine isolates (35\%) belonged to serotype II and 10 isolates (40\%) to serotype Ib (Table 2).

Molecular analysis of the cell wall-spanning domain of the $\boldsymbol{C} \boldsymbol{\beta}$-protein. To investigate DNA polymorphisms within the cell wall-spanning domain of the $\mathrm{C} \beta$-protein (Fig. 1), DNA of the GBS isolates were subjected to PCR analysis with the respective primers amplifying fragments of the $C \beta$-protein 
Table 1. Characteristics of neonatal C $\beta$-protein gene-positive GBS strains

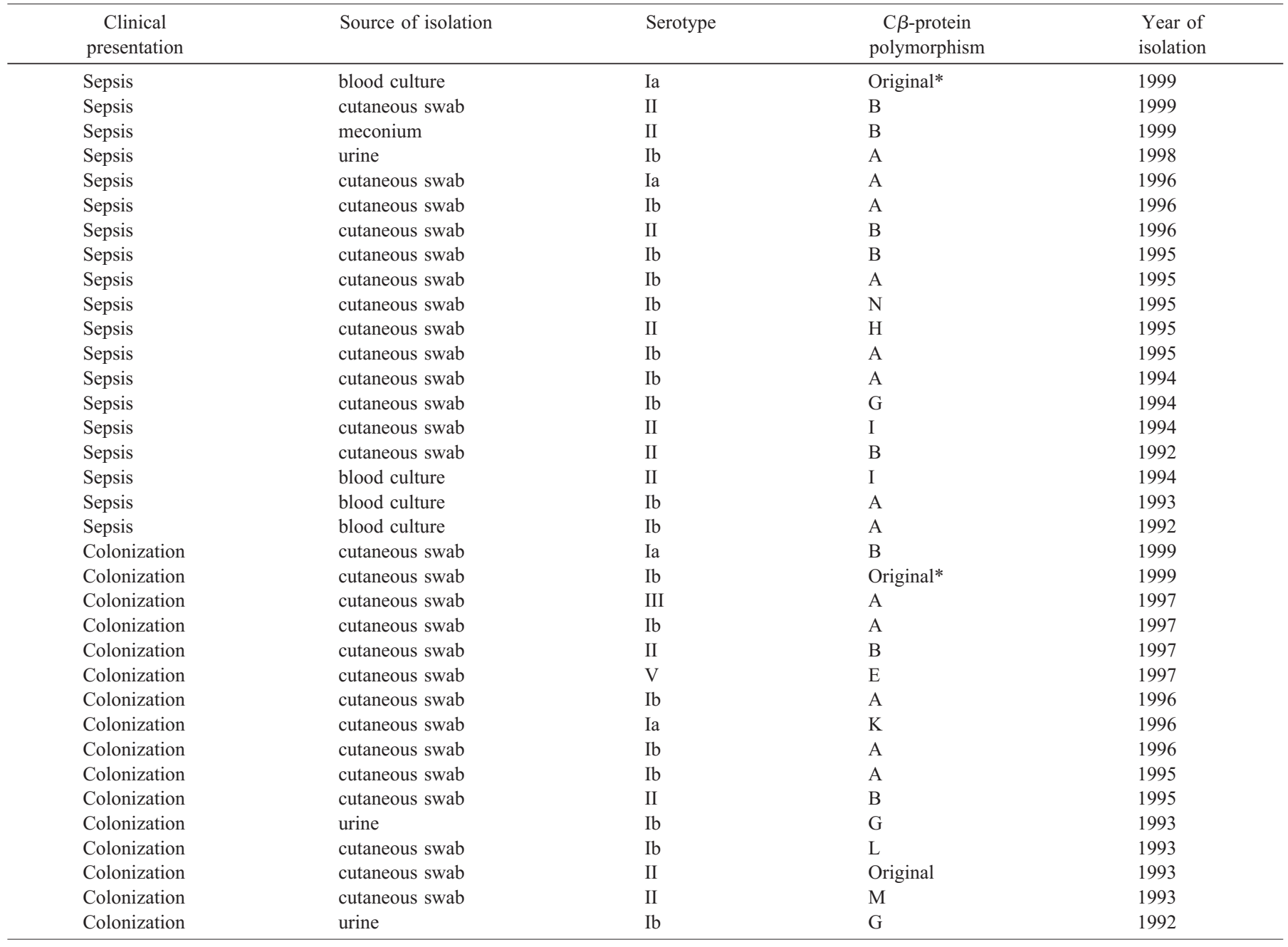

* Mutation of only two nucleotides which do not alter the open reading frame.

Table 2. Distribution of different polymorphisms of C $\beta$-protein gene according to serotypes of neonatal or maternal isolates

\begin{tabular}{|c|c|c|c|c|c|c|}
\hline \multirow[b]{2}{*}{ Polymorphism } & \multicolumn{6}{|c|}{ No. of isolates (neonatal/maternal) according to serotype } \\
\hline & Ia $(n=7)$ & $\mathrm{Ib}(n=28)$ & II $(n=20)$ & III $(n=1)$ & $\mathrm{V}(n=3)$ & $\mathrm{NT}^{*}(n=1)$ \\
\hline Large deletion (>50 bp) & $1 / 1$ & $14 / 5$ & $3 / 2$ & $1 / 0$ & $1 / 0$ & $0 / 1$ \\
\hline Small insertion & $1 / 0$ & $0 / 2$ & $0 / 0$ & $0 / 0$ & $0 / 0$ & $0 / 0$ \\
\hline Large insertion $(>50 \mathrm{bp})$ & $0 / 0$ & $2 / 2$ & $1 / 0$ & $0 / 0$ & $0 / 0$ & $0 / 0$ \\
\hline
\end{tabular}

* NT, nontypable.

gene at positions 2860-3100. As reported earlier, heterogeneity in the size length of the PCR products was observed (Fig. 2 ). The range of the size variation of the PCR products observed was from 472 to $670 \mathrm{bp}$. Sequence analysis revealed 13 different subtypes within the amplified region (Table 3 ). Only two isolates $(3 \%)$ carried a genetic sequence of this region that was identical to that described earlier by Jerlström et al. (21), which was used as a reference for comparative analysis of the different subtype sequences, and which is referred to as the original sequence. In comparison to the original sequence, the majority of GBS isolates carried either small or large DNA deletions, DNA insertions, or a combination of both (Figs. 2 and 3). The two most common DNA polymorphisms were observed in $63 \%$ of all isolates. The first one (type A), which was found in $21(35 \%)$ isolates, comprised two deletions with a length of $72 \mathrm{bp}$ and $18 \mathrm{bp}$ and corresponded to the sequence described by Hedden et al. (20). The second most frequently observed genotype was found in 17 $(28 \%)$ isolates. It carried an 18-bp deletion and was most similar to the originally described sequence data of Jerlström et al. (21). The 18-bp deletion of the gene position 3076-3093 occurred separately or in combination with other polymorphisms in 53 strains (88\%). Among all isolates investigated, both the largest deletion and largest insertion were $108 \mathrm{bp}$ in size; both the smallest deletion and the smallest insertion were $18 \mathrm{bp}$ in size. All polymorphisms occurred in the region of the gene in which elements are periodically repeated (Fig. 1). All DNA polymorphisms observed were characterized by deletions 


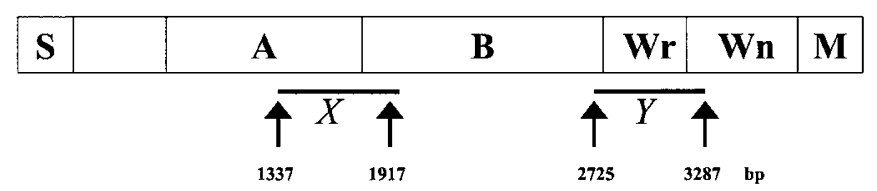

Figure 1. Domain structure of the $\mathrm{C} \beta$-protein gene [according to Jerlström et al. (21)]. Domains of known functions are boxed: $S$, signal sequence; $A$ and $B$, IgA-binding domains; $W r$, repeated region of the cell wall-spanning domain; $W n$, nonrepeated region of the cell wall-spanning domain; $M$, membranespanning domain. The total length of the $C \beta$-protein gene is $4200 \mathrm{bp}$. The region $X$ in the IgA-binding domains was amplified to detect strains harboring the $\mathrm{C} \beta$-protein. The region $Y$ is located in the cell wall-spanning domain and was analyzed in detail in this study.

or insertions of complete repetitive units. Consequently, the open reading frame was not altered in any genetic subtype analyzed. Because some combinations of different deletions and insertions lead to the same length of the PCR product, several isolates with different polymorphisms were detected only by sequence analysis (Fig. 3 and Table 3 ). Furthermore, in two isolates that showed the same PCR-product length as the original sequence, a mutation of only two nucleotides was detected, which also did not alter the open reading frame, but led to the exchange of a single amino acid in the protein sequence at position 934, where a leucine is replaced by a threonine.

To test the genetic stability of the described polymorphisms, a selected isolate (serotype Ib, genotype B) was subcultured for a total of 20 passages. Ten different single colonies per generation were analyzed by the PCR assay with the primers given above. No size differences were observed in the amplification products of the 200 different colonies tested, confirming a certain genetic stability of the polymorphisms.

When performing PCR with the primers amplifying a part of the gene region encoding for the IgA-binding domain (34), identical sizes of the PCR products of all GBS isolates were observed, suggesting a conserved genetic structure of this functional domain.

Comparison of defined genetic subtypes with GBS serotypes. Comparison of individual DNA polymorphisms with serotypes revealed that the majority of isolates with large $(>50$ bp) deletions were associated with the serotype Ib (19 of 28; Table 2). Comparison of the $\mathrm{C} \beta$-protein gene polymorphisms between serotype Ib and serotype II isolates revealed a higher frequency of rearranged (large deletions) genes in serotype Ib (68 versus $26 \% ; p=0.001$ ). Likewise, when comparing polymorphisms between serotype Ib and serotype II isolates of neonatal origin only, isolates carrying deletions $>50 \mathrm{bp}$ were found more frequently in serotype Ib (78 versus $27 \%$; $p=$ 0.01 ). When comparing polymorphisms between isolates of either neonatal or maternal origin, it became evident that 20 of $35(57 \%)$ of the neonatal isolates, but only nine of $25(36 \%)$ maternal isolates, carried large deletions $(p=0.08)$. Within serotype Ib isolates, 14 of $18(78 \%)$ neonatal isolates carried large deletions compared with five of 10 maternal isolates $(p=$ $0.13)$. In contrast, in serotype II isolates seven of nine maternal, and seven of 11 neonatal isolates showed the original nucleotide sequence or a very similar one (Table 2).

\section{DISCUSSION}

We have recently described a genetic variability within the cell wall-spanning domain of the $\mathrm{C} \beta$-protein gene in clinical isolates from newborns with sepsis, healthy newborns, and colonized adult women (13). In the present study the genetic structure of the polymorphisms was further investigated. The $\mathrm{C} \beta$-protein gene product has a signal sequence at the $\mathrm{N}$ terminus, a cell wall- and a cell membrane-spanning C-terminal domain, and two functional domains ( $\mathrm{A}$ and $\mathrm{B}$ ) that mediate binding of the Fc portion of human $\operatorname{IgA}(20,21,27)$ (Fig. 1). As outlined in the original sequence analysis by Jerlstrom et al. (21) and Heden et al. (20), there is a particular structure of the gene near the $\mathrm{C}$ terminus containing repetitive genetic elements with a short periodicity. This region was designated as XPZ motif region by Heden et al. (20) and Wr region by Jerlstrom et al. (21). The region is characterized by proline-rich stretches of amino acids with every third amino acid being a proline. Regions with a high proline content are also found in the cell wall-spanning region of several surface proteins from Grampositive cocci, in which the proline-rich sequences are located close to the membrane anchors (21). In the $\mathrm{C} \beta$-protein of GBS isolates, the proline-rich region corresponds to the cell wallspanning domain. In our collection of clinical GBS isolates we could identify significant genetic polymorphisms within this proline-rich domain. The majority of isolates had deletions, some had insertions, and others a combination of both. None of these polymorphisms altered the open reading frame, but changed considerably the number of repeats within the cell wall-spanning domain. This diversity might correspond at the protein level to the observation of Maeland et al. (35), who described two GBS strains that expressed $C \beta$-proteins of different sizes. The following evidence from that study supports this hypothesis. First, the sizes of these proteins were smaller

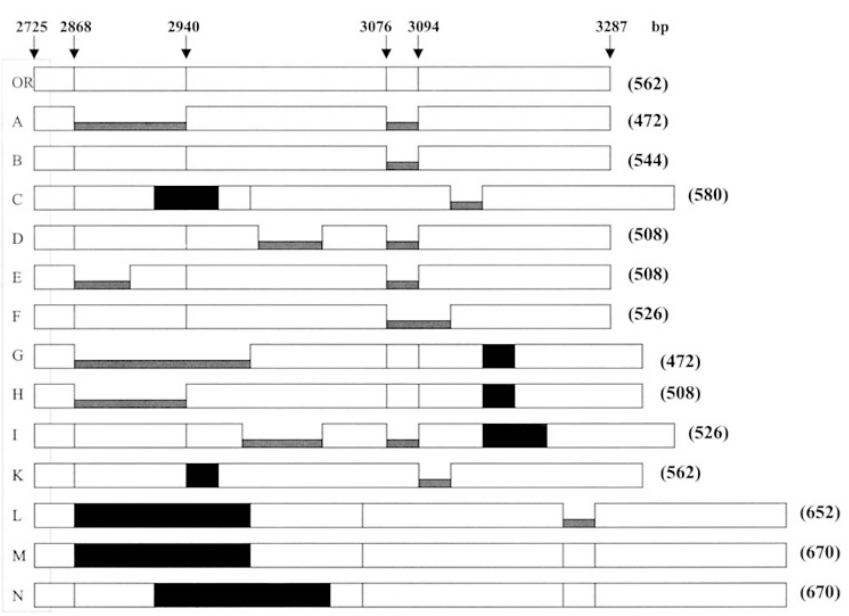

Figure 2. Schematic representation of deletions and insertions in the $\mathrm{C} \beta$ protein gene. In the first line a schematic model of the original gene sequence $(O R)$ is shown (21). The open boxes represent the unaltered parts of the original sequence. Noteworthy, the box size does not match exactly the length of the nucleotide sequence. The arrows indicate the region of the gene where the majority of deletions and insertions were observed; the exact positions are given in Figure 3. Low gray-shaded boxes indicate deletions in individual variants. The insertions are indicated by black boxes. At the right of each line the size of the amplified PCR product is shown. 
Table 3. Detailed description of DNA polymorphisms within cell wall-spanning domain encoding region of C $\beta$-protein gene

\begin{tabular}{|c|c|c|c|}
\hline Polymorphism & $\begin{array}{l}\text { Deletion with gene position and } \\
\text { size }\end{array}$ & $\begin{array}{l}\text { Insertion with gene } \\
\text { position and size }\end{array}$ & $\begin{array}{l}\text { No. of } \\
\text { isolates }\end{array}$ \\
\hline A & $\begin{array}{l}\text { del 1: pos. } 2868-2939,-72 \mathrm{bp} \\
\text { del 6: pos. } 3076-3093,-18 \mathrm{bp}\end{array}$ & & 21 \\
\hline $\mathrm{C}$ & del 6: pos. $3076-3093,-18$ bp & Ins 2: pos. $2911,+36 \mathrm{bp}$ & 3 \\
\hline $\mathrm{D}$ & $\begin{array}{l}\text { del 5: pos. } 2983-3018,-36 \mathrm{bp} \\
\text { del 6: pos. } 3076-3093,-18 \mathrm{bp}\end{array}$ & & 1 \\
\hline $\mathrm{F}$ & del 7: pos. $3076-3111,-36 \mathrm{bp}$ & & 1 \\
\hline G & del 3: pos. $2875-2982,-108$ bp & Ins 5: pos. $3130,+18$ bp & 3 \\
\hline $\mathrm{H}$ & del 1: pos. $2868-2939,-72$ bp & Ins 5: pos. $3130,+18 \mathrm{bp}$ & 1 \\
\hline I & $\begin{array}{l}\text { del 4: pos. } 2965-3018,-54 \mathrm{bp} \\
\text { del 6: pos. } 3076-3093,-18 \mathrm{bp}\end{array}$ & Ins 6: pos. $3130,+36 \mathrm{bp}$ & 2 \\
\hline K & del 6: pos. $3076-3093,-18 \mathrm{bp}$ & Ins 4: pos. $2940,+18$ bp & 1 \\
\hline
\end{tabular}

$\downarrow$ ins 1 (2875)

GAAACTCCAGATACACCGAAGATTCCAGAGCTACCTCAAGCCCCAGATACACCGCAGGCTCCAGACACACCGCATGTTCCGGAATCACCAAAGGCCCCAG

del 1 (2868-2939) ------------

del 2 (2868-2903)--

del 3 (2875-2982) -..............

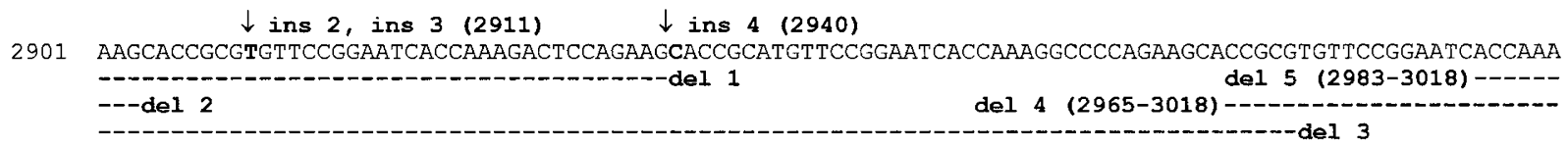

3001

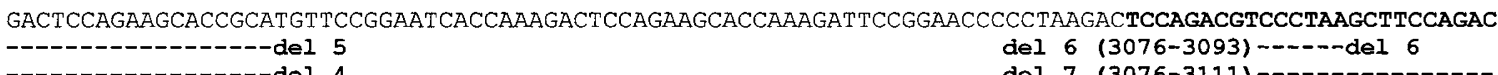

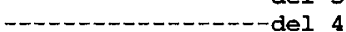

$\downarrow$ ins 5 , ins 6 (3130)

3101 GTCCCTAAGCTTCCAGACGTCCCTAAGCTTCCAGATGCACCGAAGTTACCAGATGGGTTAAATAAAGTTGGACAAGCAGTATTTACATCAACTGATGGAA $-----------d e l 7$

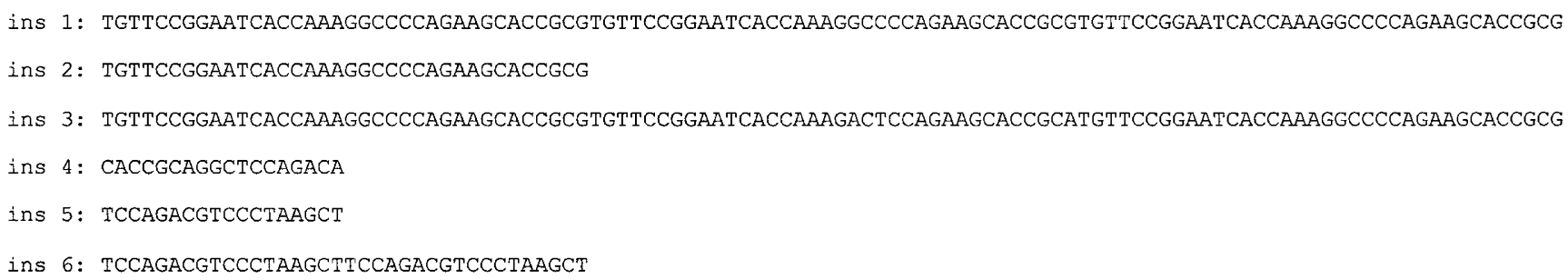

Figure 3. Results of sequence analysis of the $\mathrm{C} \beta$-protein gene variants. Deletions and insertions as compared with the original $\mathrm{C} \beta$-protein gene sequence (21) are marked. The exact nucleotide position of each variant is indicated.

than that calculated from the original sequence data: the sizes of $94 \mathrm{kD}$ and $84 \mathrm{kD}$, respectively, were well below the estimate of $120 \mathrm{kD}$ for the original protein. Second, the proteins were not anchored at the surface of the bacteria, inasmuch as the isolates could not be stained with a fluorescent antibody directed against the $\mathrm{C} \beta$-protein. Third, the proteins were not able to bind the antibody directed against the $\beta$-antigen in Western blot analysis. Nevertheless, the proteins behaved normally in terms of IgA binding, and they were secreted during bacterial growth. It was speculated by Maeland et al. (34) that the
$\mathrm{C} \beta$-protein was rearranged at the $\mathrm{C}$-terminal end, and that this was because of deletions in the proline-rich region. Likewise, other authors had also demonstrated that surface-anchoring of the $\mathrm{C} \beta$-protein varies among GBS isolates (16). Therefore, there is indirect evidence to believe that the genetic variability of the proline-rich cell wall-spanning domain that is described in this study corresponds to the previously reported phenotypic observations. One might speculate that large deletions in the cell wall-spanning domain of the $\mathrm{C} \beta$-protein gene may lead to a loss of fixation or attachment of the protein to the bacterial 
cell wall, which will result in the release of the IgA-binding domain from the bacterial surface. Blocking the binding activity of mucosal immunoglobulins not on the bacterial surface, but apart, might protect the pathogen from opsonization and killing. This hypothesis, however, remains to be proven by functional analysis.

Recently, we have demonstrated that five distinct subtypes of the $\mathrm{C} \beta$-protein gene-positive strains can be differentiated by PCR analysis of the gene region encoding cell wall-spanning (13). The sequence analysis performed in this study revealed that there is a greater genetic heterogeneity than expected previously. Some strains had larger deletions together with small insertions, which resulted in a very similar PCR product size to that of other strains with smaller deletions. Surprisingly, only a minority of $\mathrm{C} \beta$-protein gene-positive GBS isolates (two isolates, $3 \%$ ) contained the original genetic sequence that was described by Jerlström et al. (21), whereas 18 isolates (33\%) revealed a sequence with minor deletions of 18 and $36 \mathrm{bp}$. The majority of $\mathrm{C} \beta$-protein gene-positive isolates, however, showed deletions of up to $108 \mathrm{bp}$ (29 isolates, $48 \%$ ), and a minority of eight isolates $(13 \%)$, insertions of up to $108 \mathrm{bp}$. These findings reflect a considerable genetic variability within this region, which according to the limited evidence from our subculturing experiments remains fairly stable.

In summary, we describe a significant heterogeneity of the $\mathrm{C} \beta$-protein gene among clinical $S$. agalactiae isolates on the genetic level. The polymorphisms occur in the proline-rich region of the $C \beta$-protein, which corresponds to the cell wallspanning domain. They are supposed to be of functional impact in terms of an altered shedding behavior of the proteins from the bacterial surface.

Acknowledgment. The authors thank Silvia Duerre for her excellent technical assistance.

\section{REFERENCES}

1. Schuchat A 1998 Epidemiology of group B streptococcal disease in the United States: shifting paradigms. Clin Microbiol Rev 11:497-513

2. Schuchat A, Zywicki SS, Dinsmoor MJ, Mercer B, Romaguera J, O'Sullivan MJ, Patel D, Peters MT, Stoll B, Levine OS, The Prevention of Early-onset Neonatal Sepsis (PENS) Study Group 2000 Risk factors and opportunities for prevention of early-onset neonatal sepsis: a multicenter case-control study. Pediatrics 105:21-26

3. Baker CJ 1980 Group B streptococcal infections. Adv Intern Med 25:475-501

4. Baker CJ, Barrett FF 1973 Transmission of group B streptococci among parturient women and their neonates. J Pediatr 83:919-925

5. Berner R, Schumacher RF, Bartelt S, Forster J, Brandis M 1998 Predisposing conditions and pathogens in bacteremia in hospitalized children. Eur J Clin Microbiol Infect Dis 17:337-340

6. Berner R, Niemeyer CM, Leititis JU, Funke A, Schwab C, Rau U, Richter K, Tawfeek MSK, Clad A, Brandis M 1998 Plasma levels and gene-expression of G-CSF, TNF- $\alpha$, IL-1 $\beta$, IL-6, IL-8, and sICAM-1 in neonatal early-onset sepsis. Pediatr Res 44:469477

7. Gladstone IM, Ehrenkranz RA, Edberg SC, Baltimore RS 1990 A ten-year review of neonatal sepsis and comparison with the previous fifty-year experience. Pediatr Infect Dis J 9:819-825

8. Siegel JD, McCracken Jr GH 1981 Sepsis neonatorum. N Engl J Med 304:642-647

9. Nizet V, Rubens CE 2000 Pathogenic mechanisms and virulence factors of group B streptococci. In: Fischetti VA, Novick RP, Ferretti JJ, Portnoy DA, Rood JI (eds)
Gram-Positive Pathogens. American Society for Microbiology Press, Washington, DC, pp 125-136

10. Paoletti LC, Madoff LC, Kasper DL 2000 Surface structures in group B streptococcus important in human immunity. In: Fischetti VA, Novick RP, Ferretti JJ, Portnoy DA, Rood JI (eds) Gram-Positive Pathogens. American Society for Microbiology Press, Washington, DC, pp 137-153

11. Rubens CE, Wessels MR, Heggen LM, Kasper DL 1987 Transposon mutagenesis of type III group B streptococcus: correlation of capsule expression with virulence. Proc Natl Acad Sci USA 84:7208-7212

12. Wessels MR, Rubens CE, Benedi VJ, Kasper DL 1989 Definition of a bacterial virulence factor: sialysation of the group B streptococcal capsule. Proc Natl Acad Sci USA 86:8983-8987

13. Berner R, Bender A, Rensing C, Forster J, Brandis M 1999 Low prevalence of the immunoglobulin A binding $\beta$ antigen of the $\mathrm{C}$ protein among Streptococcus agalactiae isolates causing neonatal sepsis. Eur J Clin Microbiol Infect Dis 15:545-550

14. Bevanger L $1983 \mathrm{Ibc}$ proteins as serotype markers of group B streptococci. Acta Pathol Microbiol Immunol Scand Sect B 91:231-234

15. Brady LJ, Daphtary UD, Ayoub EM, Boyle MDP 1988 Two novel antigens associated with group B streptococci identified by a rapid two-stage RIA. J Infect Dis 158:965-972

16. Brady LJ, Boyle MDP 1989 Identification of non-immunoglobulin A-Fc-binding forms and low-molecular-weight secreted forms of the group B streptococcal beta antigen. Infect Immun 57:1573-1581

17. Chun CSY, Brady LJ, Boyle MDP, Dillon HC, Ayoub EM 1991 Group B streptococcal C protein-associated antigens: association with neonatal sepsis. J Infect Dis 163:786-791

18. Johnson DR, Ferrieri P 1984 Group B streptococcal Ibc protein antigen: distribution of two determinants of wild-type strains of common serotypes. J Clin Microbiol 19:506-510

19. Kvam AI, Efstratiou A, Bevanger L, Cookson BD, Marticorenca IF, George RC, Maeland JA 1995 Distribution of serovariants of group B streptococci in isolates from England and Norway. J Med Microbiol 42:246-250

20. Heden LO, Frithz E, Lindahl G 1991 Molecular characterization of an IgA receptor from group B streptococci: sequence of the structure and isolation of $\mathrm{N}$-terminal fragments with IgA-binding capacity. Eur J Immunol 21:1481-1490

21. Jerlstrom PG, Chhatwal GS, Timmis KN 1991 The IgA binding beta antigen for the C protein complex of group B streptococci: sequence determination of its gene and detection of two binding regions. Mol Microbiol 5:843-849

22. Michel JL, Madoff LC, Olson K, Kling DE, Kasper DL, Ausubel FM 1992 Large, identical, tandem repeating units in the $\mathrm{C}$ protein alpha antigen gene, $b c a$, of group $\mathrm{B}$ streptococci. Proc Natl Acad Sci USA 89:10060-10064

23. Brady LJ, Daphtary UD, Ayoub EM, Boyle MDP 1988 Two novel antigens associated with group B streptococci identified by a rapid two-stage RIA. J Infect Dis 158:965-972

24. Lancefield RC, McCarty M, Everly WN 1975 Multiple mouse-protective antibodies directed against group B streptococci. J Exp Med 142:165-179

25. Payne NR, Ferrieri P 1985 The relation of the Ibc protein antigen to the opsonization differences between strains of type II group B streptococci. J Infect Dis 151:672-681

26. Payne NR, Kim Y, Ferrieri P 1987 Effects of differences in antibody and complement requirements on phagocytic uptake and intracellular killing of "c" protein-positive and -negative strains of type II group B streptococci. Infect Immun 55:1243-1251

27. Jerlstrom PG, Talay SR, Valentin-Weigand P, Timmis KN, Chhatwal GS 1996 Identification of an immunoglobulin A binding motif located in the $\beta$-antigen of the c protein complex of group B streptococci. Infect Immun 64:2787-2793

28. Russell-Jones GJ, Gotschlich EC, Blake MS 1984 A surface receptor specific for human IgA on group B streptococci possessing the Ibc protein antigen. J Exp Med 160:1467-1475

29. Madoff LC, Michel JL, Kasper DL 1991 A monoclonal antibody identifies a protective C protein alpha-antigen epitope in group B streptococci. Infect Immun 59:204210

30. Madoff LC, Paoletti LC, Tai JY, Kasper DL 1994 Maternal immunization of mice with group B streptococcal type III polysaccharide-beta C protein conjugate elicits protective antibody to multiple serotypes. J Clin Invest 94:286-292

31. Michel JL, Madoff LC, Kling DE, Kasper DL, Ausubel FM 1991 Cloned alpha and beta $\mathrm{C}$ protein antigens of group $\mathrm{B}$ streptococci elicit protective immunity. Infect Immun 59:2023-2028

32. Madoff LC, Hori S, Michel JL, Baker CJ, Kasper DL 1991 Phenotypic diversity in the alpha C protein of group B streptococci. Infect Immun 59:2638-2644

33. Mawn JA, Simpson AJ, Heard SR 1993 Detection of the C protein gene among group B streptococci using PCR. J Clin Path 46:633-636

34. Maeland JA, Brakstad OG, Bevanger L, Kvam AI 1997 Streptococcus agalactiae $\beta$ gene and gene product variations. J Med Microbiol 46:999-1005

35. Maeland JA, Bevanger L, Iversen G, Lyng RV 1999 bca, beta gene and gene product divergency in reference and prototype strains of Streptococcus agalactiae. Clin Diagn Lab Immunol 6:986-988 